\title{
Clinical study of post partum eclampsia in a tertiary care hospital
}

\author{
R. Bharathi*, K. P. Mohana Sundari, R. Deeba Jayanthi
}

Department of Obstetrics and Gynecology, Government Mohan Kumaramangalam Medical College Hospital, Salem, Tamil Nadu, India

Received: 19 September 2016

Accepted: 10 October 2016

*Correspondence:

Dr. R. Bharathi,

E-mail: drbharathiramasamy@gmail.com

Copyright: () the author(s), publisher and licensee Medip Academy. This is an open-access article distributed under the terms of the Creative Commons Attribution Non-Commercial License, which permits unrestricted non-commercial use, distribution, and reproduction in any medium, provided the original work is properly cited.

\section{ABSTRACT}

Background: The study was done to analyze epidemiological factors associated with postpartum eclampsia and to assess the maternal outcome.

Methods: This is a retrospective study done in a tertiary care hospital, Govt. Mohan Kumaramangalam Medical College Hospital, Salem, Tamil Nadu between Jan 2015 to Dec 2015. Case records of all the postpartum eclampsia patients admitted during this period were analyzed.

Results: This study showed that the incidence of postpartum eclampsia in our hospital was 9.3 per 1000 deliveries. It is more common in the age group of $21-25$ years $(52 \%)$ and frequent occurrence in primi para (50.7\%). Commonest mode of delivery was vaginal route $(63 \%)$. The occurrences of seizures were common between 48 hours to 7 days $(30.7 \%)$. The mortality was $6(10.7 \%)$ out of 56 maternal deaths that occurred during the study period.

Conclusions: Postpartum eclampsia is still one of the most common obstetric emergencies which have a significant role in maternal mortality. Regular antenatal care alone is not enough; they also need regular postnatal follow up care and health education.

Keywords: Postpartum eclampsia, Maternal mortality, CVT

\section{INTRODUCTION}

Postpartum eclampsia is defined as the development of seizures during puerperium that cannot be attributed to any other cause. ${ }^{1}$ It is mostly sudden because of its ill understood etiology and most of the time not associated with prodromal symptoms. With improvement in antenatal care and intervention definitely there is a reduction in the AP eclampsia. In AP eclampsia timely intervention with $\mathrm{MgSO}_{4}$ at the $\mathrm{PHC}$ level has reduced the morbidity and mortality. But the same degree of vigilance and surveillance is not being followed after delivery. Postpartum eclampsia is potentially tragic complication as AP eclampsia and hence follows up of all delivered patients whether they had preeclampsia in antenatal period or not remains the corner stone in preventing postpartum eclampsia. Incidence of hypertensive disorders in India is found to be increasing as observed by the maternal eclampsia registry. ${ }^{2}$ This study is done to assess the problem of postpartum eclampsia in our population and ways to prevent them as this contributes significantly to maternal mortality.

\section{METHODS}

This is retrospective study of all postpartum eclampsia patients admitted between Jan 2015 to Dec 2015 in the Department of $\mathrm{O}$ and G, Govt. Mohan Kumaramangalam Medical College Hospital, Salem, Tamil Nadu. All the required data were collected from MRD. The following epidemiological factors were observed like age, parity, 
pre-existing hypertension (or) eclampsia, mode of delivery, recurrence of seizure and maternal outcome.

\section{RESULTS}

During the study period for 6976 deliveries 65 cases were admitted with postpartum eclampsia. So the incidence was $0.9 \%$. Postpartum eclampsia was more common in the age group of $21-25(52 \%)$. Most of the postpartum eclampsia occurred in primi para (51\%). Only $4.6 \%$ (3) of patients had prior AP eclampsia and 20\% (13) had preeclampsia prior to postpartum eclampsia. Regarding the mode of delivery majority of patients had vaginal delivery $41(63 \%)$. 6 cases $(9 \%)$ of postpartum eclampsia delivered in our institutions whereas, 59 cases (91\%) were delivered in other institutions and referred here as postpartum eclampsia. 6\% were referred from Primary Health Centre, $80 \%$ were referred from Government Hospitals, $13 \%$ from other medical colleges. 16 (24.6\%) patients had seizures in less than 48 hours. 20 (30.7\%) patients had seizures between 48 hours to 7 days. 16 $(24.6 \%)$ patients had seizures between 8 to 14 days and 13 cases $(20 \%)$ had seizures after 14 days. $84.6 \%$ of patients belong to rural areas. 18 cases $(27.6 \%)$ had headache prior to seizures. 14 cases (21.5\%) had vomiting prior to seizures. Although all patients received $\mathrm{MgSO}_{4}$, the recurrent rate of seizures was $4.6 \%$. None of the patients developed $\mathrm{MgSO}_{4}$ toxicity. Cases who were diagnosed to have CVT were put on phenytoin, antiedema measures and anticoagulants.

Table 1: Age distribution.

\begin{tabular}{|ll|}
\hline Age in years & Percentage \\
\hline$<20$ & $20 \%$ \\
\hline $21-25$ & $52 \%$ \\
\hline $26-30$ & $25 \%$ \\
\hline $30-35$ & $3 \%$ \\
\hline
\end{tabular}

Table 2: Parity.

\begin{tabular}{|ll|}
\hline Parity & Percentage \\
\hline Para 1 & $50.7 \%$ \\
\hline Para 2 & $32.3 \%$ \\
\hline Para 3 & $15.5 \%$ \\
\hline Para 4 & $1.5 \%$ \\
\hline
\end{tabular}

Table 3: Habitat.

\begin{tabular}{|ll|}
\hline Habitat & Percentage \\
\hline Urban & $15.3 \%$ \\
\hline Rural & $84.7 \%$ \\
\hline
\end{tabular}

Table 4: Mode of delivery.

\begin{tabular}{|ll|}
\hline Route of delivery & Percentage \\
\hline Vaginal & $63 \%$ \\
\hline LSCS & $37 \%$ \\
\hline
\end{tabular}

Anemia was a significant co-morbid factor and was associated in 16 cases (24.6\%). Among 65 patients $15.3 \%$ had PRES and $10.7 \%$ had CVT and $74 \%$ had normal CT and MRI findings.

Table 5: Referral.

\begin{tabular}{|ll|}
\hline Referral & Percentage \\
\hline PHC & $6.7 \%$ \\
\hline GH & $80 \%$ \\
\hline Medical College & $13.3 \%$ \\
\hline
\end{tabular}

Table 6: Timing of seizures.

\begin{tabular}{|lll|}
\hline Occurrence of Seizure & Timing & Percentage \\
\hline \multirow{2}{*}{$\begin{array}{l}\text { Less than } 48 \text { hours } \\
(24 \%)\end{array}$} & $<12$ hours & $12 \%$ \\
\cline { 2 - 3 } & $12-24$ hours & $6 \%$ \\
\cline { 2 - 3 } 48 hours- 7 days & & $6 \%$ \\
\hline $8-14$ days & $30.7 \%$ \\
\hline$>14$ days & & $24.6 \%$ \\
\hline
\end{tabular}

\section{DISCUSSION}

During our study period $59.4 \%$ cases had AP eclampsia among total eclampsia cases which had a similar observation in a study done by Hemkanta et al. ${ }^{3}$ Recent years have shown an increased in the incidence of postpartum eclampsia probably due to better prenatal care and prophylactic use of $\mathrm{MgSO}_{4}$ in severe preeclampsia, AP eclampsia and IP eclampsia. ${ }^{4}$ In a study by Chames et al, who found with improvement in antenatal care, early deduction of preeclampsia and prophylactic use of $\mathrm{MgSO}_{4}$, there has been increasing shift in the incidence of eclampsia towards the postpartum period. ${ }^{5}$ Sibai et al reported $18.25 \%$ postpartum eclampsia cases whereas in our study we had $35 \%$ postpartum eclampsia. ${ }^{6}$ This $35 \%$ of postpartum eclampsia is comparable to study done by S. K. Rath et al and Chames et al. ${ }^{5,7}$

The incidence of postpartum eclampsia 0.9 per 1000 maternities in our study whereas in the study done by Kayem et al the incidence was very low ( 0.1 per 1000 maternities). ${ }^{8}$

Among the women with postpartum eclampsia $12 \%$ $(n=8)$ of women had seizures $<12$ hours following delivery, whereas in study done by Kayem et al it is very high as high as $70 \%{ }^{8}$ Most of the women had seizures 48 hours after delivery (75.4\%) which is comparable with the study done by Chames et al in which the incidence is $79 \% .20 \%$ of patients were previously diagnosed to have preeclampsia in our study which is comparable to the study done by Chames et al. ${ }^{5}$ In our study $27.6 \%$ had headache and $21.5 \%$ had vomiting prior to seizure whereas in the study done by Chames et al the incidence of prodromal symptoms were very high. ${ }^{5}$ The percentage of CVT is $10 \%$ which is also very high when compared to the study done by Runjun Doley et al. The maternal 
mortality was $6(10.7 \%)$ out of 56 deaths that occurred in that year. ${ }^{10}$ Out of the 6 deaths, 1 had normal CT/MRI and rest of them had CVT.

\section{CONCLUSION}

Currently because of the assess to AN care has improved, the overt cases of preeclampsia are identified early and treated. This could be the reason for the decrease in AP eclampsia and the rising trend in postpartum eclampsia. Conventionally it is said that postpartum eclampsia usually occurs in $<48$ hours. But it is proved beyond doubt that it is not so, as seen in our study that timing of seizures ranges throughout the puerperal period. In our study there was 1 patient who had seizures at $32^{\text {nd }}$ postpartum day. Vigilance and intense surveillance during postpartum period has to be done to reduce postpartum eclampsia. Health educations regarding the prodromal warning symptoms have to be stressed upon to all postpartum women and peripheral health care providers. In our part of the society drinking water in the postnatal period considered as a taboo, so many women consume very little water which may also be a contributing factor leading to an increase in postpartum eclampsia. Regarding this health education should be given to all women during the antenatal period itself. Postpartum eclampsia is still on the most common obstetric emergency which has a significant role in maternal mortality. Excellent antenatal care in our part of the county has resulted in shift of eclampsia towards the postpartum period. Hence regular antenatal care alone is not enough, they also need to regular postnatal follow up care throughout puerperium.

Funding: No funding sources Conflict of interest: None declared

Ethical approval: The study was approved by the Institutional Ethics Committee

\section{REFERENCES}

1. Singh BM, Mishra R. Hypertensive disorders, Mishra R, editor. Ian Donalds Practical Obstetric Problem, Seventh edition, BI Publications Pvt Ltd; New Delhi; 2014:142-75.

2. Gupta S, Wagh G. Preeclampsia, Journal of Obstetrics and Gynaecology. 2014 Feb;64(1);4-13.

3. Sarma HK, Talukdar B, Eclampsia. A clinical prospective study in a referral hospital. Journal of Obstetrics and Gynaecology Barpeta, 2014;I(1);5761.

4. Bansal V, Damania KR. Hypertensive disorders of pregnancy, Amarnath B, Sabaratnam A, Kaizad RD, Daftary SN, editor. Arias Practical Guide to Highrisk pregnancy and delivery. A South Asian Perspective, $4^{\text {th }}$ edition, Elsevier: New Delhi; 2015.

5. Chames MC, Livingston JC, Ivester TS, Barton JR, Sibai BM. Late postpartum eclampsia: A preventable disease; American Journal of Obstetrics Gynaecology. 2002;186(6):1174-77.

6. Sibai BM. Hypertension in pregnancy. In: Gabbe SG, Niebyl JR, Simpson JL, editors. Obstetrics: normal and problem pregnancies. $3^{\text {rd }}$ ed. New York: Churchill-Livingstone, 1996:935-996.

7. Rath SK. Clinical Study of Postpartum eclampsia, International Journal of Science and Research (IJSR). 2016;5(3):1555-7.

8. Kayem G, Kurinczuk JJ, Spark P, Brocklehurst P, Knight M. System UKOS, Maternal and Obstetric factors associated with delayed postpartum eclampsia; a national study population, Acta Obstet Gynecol Scand, 2011;90(9);1017-23.

9. Doley R. Clinical study of eclampsia in a tertiary care hospital, Indian Journal of Science and Technology. 2016;9(29).

10. Sundari KPM, Priya RP, Subathra, Maternal mortality; analysis of causes and preventable factors. Int J Reprod Contracept Obstet Gynecol. 2016;5:1719-21.

Cite this article as: Bharathi R, Sundari KPM, Jayanthi RD. Clinical study of post partum eclampsia in a tertiary care hospital. Int J Reprod Contracept Obstet Gynecol 2016;5:3728-30. 